報 文

\title{
オゾナイザのオゾン発生特性について
}

\section{On the Ozone Generation Characteristics of the Ozonizer}

\author{
橘川䖉・今 泉
}

摘要

1. 目 的

オゾナイザの電気的諸特性は従来からよく研究され知られておりオゾナイザの設計手法として実用されているが, こてでは従来あまり解明されていなかったオゾン生成機構とオゾナイザの運転条件, 電極構造との関係を考察する ことによりオゾナイザの設計指針を得る.

\section{2. 成 果}

通常の実用条件範用の実機オゾナイザにおいては, 冷却水温度, 放電空隙長, 露点, 放電電力密度等の諸条件が 決められるとオゾン濃度 $x$ は $x=x_{0}\left(1-e^{-\alpha^{*} W / Q_{N}}\right)$ で表わすことが妥当である。乙こで $x_{0}$ : 極限オゾンの濃度, $\alpha^{*}$ : オゾナイザにより決る定数, $W$ : 投入電力. 更に前式が判明すればオゾナイザの諸元を求め得ることが分っ た。

またオゾナイザの電極の放電空陌長は放電状態および気体温度に与える影響が大きく，放電空隙長が $2 \mathrm{~mm}$ 程度で 単位放電電力当りのオゾン収量即ちオゾン収率が向上する事実が実験的に得られるしオゾン生成機構に関する理論 式からあ裏づけられる.

\section{1.はじめに}

ここ数年来環境公害防止技術としてオゾンの用途が 著しく拡大しているととは周知の事実である。その強 い酸化力を利用し脱臭, 脱色, 有機物除去等多目的用 途に広く使用されて来ており今後更に上水処理, 排水 の三次処理等に大量のオン゙ンの需要が見込まれる.乙 のようなすう勢にあって機器としてのオゾナイザの研 究開発が鋭意行われ新しいオゾナイザが実用化されて 来ている. 無声放電によるオゾン発生法は古くから実 用されているが, 最近に到ってオゾナイザ放電電極単 位面積当りのオゾン生成量, 単位放電電力当りのオン゙ ン生成量即ちオゾン収率, 発生オゾン濃度が著しく増 大した．従来通常運転条件でのオゾン濃度は10 14 g $/ N \mathrm{~m}^{3}$ 程度であったが現在はオゾンの利用技術の面か ら15〜20 g/ $\mathrm{m} \mathrm{m}^{3}$ が実用されており, 今後更に高濃度 の需要む予想される。一方オン゙ン収率はオゾン濃度に

* 三菱電機 (株) 名古屋製作所
密接な関連性があるが例えばオゾン濃度 $12 \mathrm{~g} / N \mathrm{~m}^{3}$ で $0.95 \sim 1.0 \mathrm{mg} / \mathrm{min} \cdot \mathrm{W}$ (電力効率では $16.7 \sim 17.5 \mathrm{~kW}$ ・ $\mathrm{Hr} / \mathrm{kg}$ ) であったものが $1.2 \sim 1.4 \mathrm{mg} / \mathrm{min} \cdot \mathrm{W}$ (同 12〜 $13.9 \mathrm{~kW} \cdot \mathrm{Hr} / \mathrm{kg}$ ）と向上した. 乙の原因は主に オゾナイザ放電電極構造の大幅な改良に依るものであ る. この報告は最近明らかにされたオゾン生成機構 ${ }^{1}$, 2), 3) とオゾナイザ運転条件, 電極構造との関係を当社 のオゾナイザから得たデータに基づいて考察し，オゾ ン発生に関する諸特性を明らかにすることによりオン゙ ナイザの設計指針をまとめたものである.

具体的検討に供した対象機種としては, 商用周波数 及び高周波数電源を使用して実用されている汎用オゾ ナイザであり, いわゆる高放電密度即ち単位面積当り の放電々力が, $1 \mathrm{~W} / \mathrm{cm}^{2}$ 以上の大形オゾナイザ(単機 容量 $50 \sim 60 \mathrm{~kg} / \mathrm{Hr}$ ）については今回は除外した.

\section{2. オソナイザの構造}

無声放電式オゾナイザの原理的な構造図は図-1に示 すようにガラス等誘電体と放電空隙を介して高圧電極 


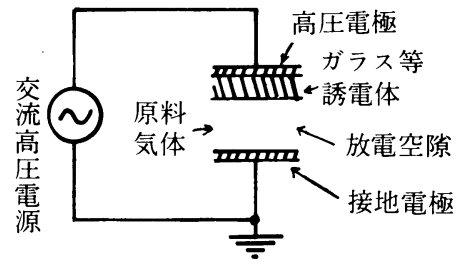

図-1 無声放電式オゾナイザの原理図

と低圧電極を対向させた構造をしている，両電極間に 交流高電圧を印加して放電空隙に無声放電を発生させ, 同空隙に供給する空気又は酸素ガスの一部をオゾン化 する．無声放電を生ずるためには，両電極間に誘電体 が介在する必要があり, 電極構造については多種多様 の形状で実用化されている，本報告では，現在広く利 用されている高圧および低圧電極を同軸円筒に配した 円筒多管式オゾナイザについて記述する.

オゾナイザの主要構成は次の通りである.

（1）オゾン発生器（オゾン発生缶体, 高圧電極管, 高 圧ヒューズ等を含む.)

(2) 高圧変圧器, 誘導電圧調整器, 力率改善用リアク トル，高周波数電源を使用する場合は誘導電圧調整 器, 力率改善用リアクトルに代り高周波インバータ.

（3）気体乾燥機およびオゾン発生器用冷却装置.

（4）制御盤および計装装置（オゾン濃度計ほか）。

これら主要構成機器によるオゾナイザ概略フローを 図-2に示している，乙てでは主要構成機器であるオゾ ン発生器および高圧電極管を中心にオゾナイザの概要 を説明しておく

\section{1 オソン発生器}

図-2に工業化されているオゾン発生器の概略構造を 示す.オゾン発生容量によって異るが，一缶体内には 数十ないし数百本からの低圧および高圧電極管対が収

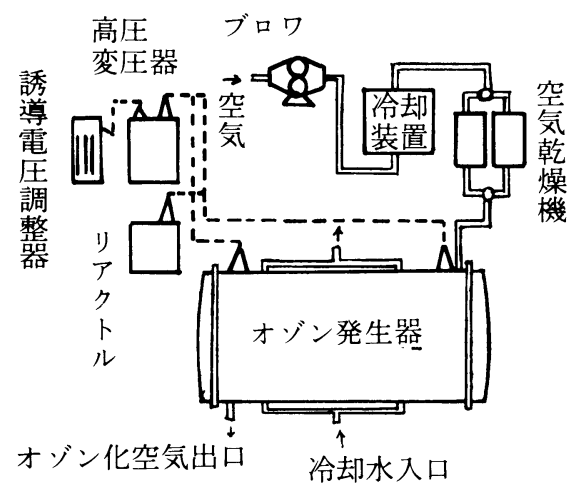

図-2 オゾナイザフロー図
納されている。乙れら両電極間には $50 \mathrm{~Hz}$ または $60 \mathrm{~Hz}$ の交流高電圧を印加するか適宜に高周波数の高電圧を 印加して放電々力密度の増加を計っている．性能のす ぐれたオゾナイザを設計するに当っての基本的な条件 は

（1）十分に除湿された乾燥気体が準備される。

（2）放電時の気体温度が十分に低く保たれる。

（3）安定した無声放電の状態が保たれる。

の 3 条件を満足するように各機器の仕様拈よび構造 を設計することである. 図一2のオゾン発生器において は, 気体原料が前段の気体乾燥機により十分除湿され た乾燥気体として缶体の一方から供給され，両電極管 間隙を通過後オゾン化気体として取り出される。乙の 間に放電空隙部之高圧電極管は金属接地電極管周囲に 設けられた冷却水にて冷却される.オゾン発生量の調 整は両電極管に印加する交流高電压または周波数を調 整することにより行っている，高圧電極管，高圧七ュ 一ズ等の出し入れなど内部点検は缶体の内形屝を開い て行う。両電極管の構造, 配置は前述の基本諸条件を 満足するように決められる．更には保守点検の容易性 等が設計の基準となる。

\section{2 高压電極管}

図-3には本文の各種試験データを得た高圧電極管と その周辺構造および表 1 亿概略仕様を示す。なおてれ ら高圧電極管は当社オゾナイザ用として現在広く実用 されている，同図に示すように一端が先封じされたガ ラス管の内面にアルミ溶射し，乙れが高圧電極管を形 成している，放電空隙長はスペーサで気体流通に支障 のないよう均一に保持されている。 また図示してない が高圧電極管端部には異常放電防止処置を施している

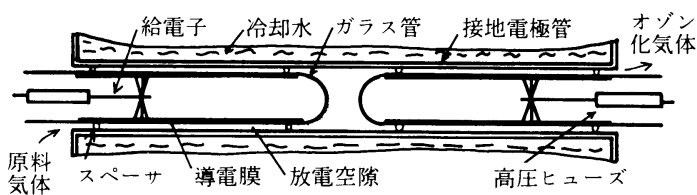

図-3 電極管構造

表 1 高圧電極管概略寸法

\begin{tabular}{|c|c|}
\hline 誘電体材質 & $\begin{array}{l}\text { 三菱電機中央研究所開発 } \\
\text { のオゾナイザ専用ガラス }\end{array}$ \\
\hline 長 & $1.3 \mathrm{~m}$ \\
\hline 直 & $81 \mathrm{~mm} \varnothing$ \\
\hline 導 電 膜 & アルミ溶射 \\
\hline 放電空隙長 & $2 \mathrm{~mm}$ \\
\hline
\end{tabular}


本文の結論として得られるてとであるが，オゾナイザ にとって高圧電極管はその性能の優劣がそのままオゾ ナイザの性能を決めてしまう重要な要素の一つである. 具体的には高圧電極管の性能が単位放電電力について 得られるオゾン収量即ちオゾン収率を決めると考えて よく，また同時に電極単位面積当りの投入電力を増大 しオン゙ン発生器のコンパクト化にあ寄与している。

\section{3. オソナナイザの特性}

\section{1 オゾナイザの電気特性}

無声放電の電気的特性は十分解明されており電気的 等価回路の計算によって放電電圧, 放電電流抒よび放 電電力に関する特性が求められる．無声放電において は, 誘電体を介しての放電であるため, 電源電圧の上 昇に従って空隙の電位差が放電滅火電圧 $V_{\mathrm{B}}$ 迄下った 所で放電が止まる．図-4に $V_{s}$ および $V_{e}$ の関係波形を 示している．無声放電の等価回路は $C_{g}$ と $C_{a}$ をそれぞ れ誘電体と空隙の単位面積当りの静電容量, 放電面積 を $S$ とると

放電時の静電容量 $\quad C_{1}=C_{g} S$

非放電時の静電容量 $C_{2}=\frac{C_{a} C_{g} S}{C_{a}+C_{g}}$

となる。

また放電電力 $W$ は次式で示される.

$$
\begin{aligned}
W & =f C_{g} S\left(V_{s}+V_{e}\right)\left\{2 E_{m}-\left(1+\frac{C_{a}}{C_{g}}\right)\left(V_{s}+V_{e}\right)\right\} \\
& =f S \frac{C_{g}^{2}}{C_{a}+C_{g}} E_{b}\left(2 E_{m}-E_{b}\right)
\end{aligned}
$$

ここで $f:$ 周波数

$E_{m}:$ 印加電圧のピーク值

$E_{b}:$ 放電休止を始める電圧で $\left(1+\frac{C_{a}}{C_{g}}\right)$

$\left(V_{s}+V_{e}\right)$ 亿等しい.

(3)式で分るように放電電力は周波数 $f$, 印加電圧の ピーク值によって決まる．即ち印加電圧の実効值には 無関係ではあるが，放電電力が間欠的に投入されるこ とはオゾン収率の面から好ましくないので，特に高周 波電源を使用する場合は電圧，電流波形に留意しなけ

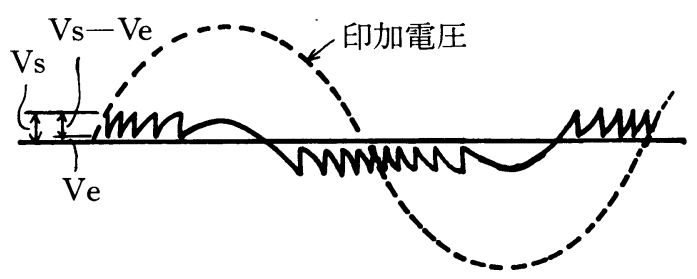

図-4 印加電圧とVs, $\mathrm{Ve}$
ればならない，次に放電電力に影響を与える要因とし て(3)式で $W$ は $C_{g}$ にほぼ比例している。実用的には $C_{a} \doteqdot \frac{1}{10} C_{g}$ であるから $C_{a} / C_{g}$ の項は影響が少ない. また放電開始電圧 $V_{s}$ は金属の火花電圧にほぼ等しい 亡考えられ， $V_{s}+V_{e}=a+b P$ で与えられる.）こてで $a$ は放電空隙長 $d$ 亿無関係な定数, $b$ は $d$ 亿関係する 定数, $P$ は気体圧力. また(3)式で $f, S, C_{g}, C_{a}, E_{m}$ をそれぞれオゾナイザで決まる定数として $d W / d E_{b}=$ 0 より放電電力 $W$ は $E_{b}=E_{m}$ で最大值 $W=f S E_{m}^{2}$ $C_{g}^{2} /\left(C_{a}+C_{g}\right)$ を得る。しかし実用機においてはオン ンを使用する立場から気体圧力 $P$ が $0.2 \sim 0.7 \mathrm{~kg} / \mathrm{cm}^{2}$ 程度に決められる場合が多く，また後に詳しく述べる が，放電空隙長 $d$ は高圧電極管の効果的な冷却を行 い, 安定した無声放電を維持し, 且つ電極管製作技術 を勘案すれば $1.5 〜 2.0 \mathrm{~mm}$ 程度となる

従っててれら諸事情より $E_{b}$ が決められている。な 抢定電流方形波式高周波インバー夕使用時も放電電力 は(3)式で与えられる.'

\section{2 オソン発生特性}

\section{2.1 オソン生成反応}

無声放電によるオゾン生成反応と一連の理論式につ いては田畑ら ${ }^{1), 2)}$ により解明されている。 ます酸素中 のオン゙ン生成反応は次のように考えられている

$$
\begin{array}{lll}
\mathrm{O}_{2}+e & \stackrel{k_{1}}{\rightarrow} & 2 \mathrm{O}+e \\
\mathrm{O}+\mathrm{O}_{2}+M & \stackrel{k_{2}}{\longrightarrow} & \mathrm{O}_{3}+M \\
\mathrm{O}_{3}+\mathrm{O} & \stackrel{k_{3}}{\longrightarrow} & 2 \mathrm{O}_{2} \\
\mathrm{O}_{3}+e & \stackrel{k_{4}}{4} & \mathrm{O}_{2}+\mathrm{O}+e
\end{array}
$$

反応速度定数 $k_{1}, k_{4}$ は放電状態に依存し, $k_{2}, k_{3}$ は反応空間の気体温度に依存する．Mは三体衝突の第 三物体であり酸素中で殆んど $\mathrm{O}_{2}$ となる. (4)〜 (7)式よ り得られる反応速度方程式から $\left[\mathrm{O}_{3}\right] /\left[\mathrm{O}_{2}\right]$ を時間 $t$ の関数として求めると次式となる.

$$
\begin{aligned}
& \left(1+\frac{\left[\mathrm{O}_{3}\right]}{\alpha\left[\mathrm{O}_{2}\right]}\right)^{(\alpha-\gamma)}\left(1+\frac{\left[\mathrm{O}_{3}\right]}{\beta\left[\mathrm{O}_{2}\right]}\right)^{(\alpha-\beta)}= \\
& =\exp \left\{-2(\alpha-\beta) k_{4}(e) t\right\} \\
& \alpha=\frac{1}{2} \frac{k_{1}}{k_{4}}\left\{1+\sqrt{1+4 \frac{k_{4}}{k_{1}} r}\right\} \\
& \beta=\frac{1}{2} \frac{k_{1}}{k_{4}}\left\{1-\sqrt{1+4 \frac{k_{4}}{k_{1}} r}\right\} \\
& r=k_{2}(M) / k_{3}
\end{aligned}
$$

オゾン分解が無視できる反応初期過程では(8)式は次 式と近似できる。 
$\left[\mathrm{O}_{3}\right] /\left[\mathrm{O}_{2}\right]=2 k_{1}[e] t$

[ $e$ ] $t$ は放電電力 $W$ と大気換算流量 $Q_{N}$ との比 $W /$ $Q_{N}$ (比電力）に比例するとして表現できる.

$$
\begin{gathered}
\lceil e] t=\frac{\kappa}{q v_{d e} E / P} \cdot \frac{n_{g}}{P} \cdot \frac{W}{Q_{N}} \equiv C_{1} \frac{W}{Q_{N}} \cdots \cdots(13) \\
\text { ここで } \quad x: \text { 全放電電流の中で電子が荷電担体とな } \\
\text { る割合 } \\
q: \text { 電子の電荷量 } \\
E: \text { 放電電界 } \\
v_{d e}: \text { 電子のドリフト速度 } \\
N_{g}: \text { 気体の密度 } \\
P: \text { 気体の压力 }
\end{gathered}
$$

(13)式を用いると(12)式は次式となる.

$$
\begin{aligned}
\eta_{\max } & =\left(\frac{Y_{\mathrm{O}_{3}}}{W}\right)_{\max } \equiv\left(\frac{\left[\mathrm{O}_{3}\right]}{\left[\mathrm{O}_{2}\right]+\left[\mathrm{O}_{3}\right]}\right) \frac{Q_{N}}{W} \\
& \simeq \frac{\left[\mathrm{O}_{3}\right\rfloor}{\left\lceil\mathrm{O}_{2}\right\rfloor} \cdot \frac{Q_{N}}{W}=2 k_{1} C_{1} \quad \ldots \ldots \ldots \ldots
\end{aligned}
$$

$Y_{\mathrm{O}_{3}}$ : 単位時間当りのオゾン生成量

また $W / Q_{N}$ が大きくなるとオン゙ン濃度は定常値に 達し次式となる。

$$
\left(\left[\mathrm{O}_{3}\right] /\left[\mathrm{O}_{2}\right]\right)_{\mathrm{ss}}=-\beta
$$

空気中の場合は酸素の場合の素反応(4) (7)式に次の 反応が付加されると考えられている。

$$
\begin{array}{lllr}
\mathrm{O}+\mathrm{O}_{2}+\mathrm{N}_{2} & \stackrel{k_{2}^{\prime}}{\longrightarrow} & \mathrm{O}_{3}+\mathrm{N}_{2} & \cdots \cdots(16) \\
\mathrm{N}_{2}+e & \stackrel{k_{\mathrm{N}_{1}}}{\longrightarrow} & \mathrm{N}_{2}^{*}+e & \cdots \cdots(17) \\
\mathrm{N}_{2}^{*}+\mathrm{O}_{2} & \stackrel{k_{\mathrm{N}_{2}}}{\longrightarrow} & 2 \mathrm{O}+\mathrm{N}_{2} & \cdots \cdots(18) \\
\mathrm{N}_{2}^{*}+\mathrm{N}_{2} & \stackrel{k_{\mathrm{N}_{3}}}{\longrightarrow} & \mathrm{N}_{2}+\mathrm{N}_{2} & \cdots \cdots(19) \\
\mathrm{N}_{2}^{*}+\mathrm{O}_{2} & \stackrel{k_{\mathrm{N}_{3}}}{\longrightarrow} & \mathrm{O}_{2}+\mathrm{N}_{2} & \cdots \cdots(20) \\
\mathrm{N}_{2}^{*}+\mathrm{O}_{3} & \stackrel{k_{\mathrm{N}_{4}}}{\longrightarrow} & \mathrm{O}_{2}+\mathrm{O}+\mathrm{N}_{2} \cdots \cdots(21)
\end{array}
$$

$N_{2}^{*}$ は酸素分子を解離するに十分なエネルギーレベ ルにある励起窒素分子である.

反応初期過程では次式が成立する.

$$
\begin{aligned}
& {\left[\mathrm{O}_{3}\right] /\left[\mathrm{O}_{2}\right]=2 k_{1 a} C_{1} W / Q_{N}} \\
& \eta_{\max }=2 k_{a 1} C_{1} \\
& k_{1 a}=k_{1}\left\{1+\frac{k_{\mathrm{N}_{1}} / k_{1} \cdot\left[\mathrm{N}_{2}\right] /\left[\mathrm{O}_{2}\right]}{1+k_{\mathrm{N}_{3}^{\prime}} / k_{\mathrm{N}_{2}}+k_{\mathrm{N}_{3}} / k_{\mathrm{N}_{2}} \cdot\left[\mathrm{N}_{2}\right] /\left[\mathrm{O}_{2}\right]}\right\}
\end{aligned}
$$

従って酸素の場合の $k_{1}$ を $k_{1 a}$ に置換えたものと形の 上で一致する．オゾン分解す考虑した全過程について 屯酸素の場合之同様に $W / Q_{N}$ の大きい所で定常値を 持ち $W / Q_{N}$ の増加に従って $\left[\mathrm{O}_{3}\right] /\left[\mathrm{O}_{2}\right]$ が直線的に 変化する初期状態加ら次第に定常值に達する。

\section{2.2 オソン発生特性の実験式}

先に述べた(8)式は反応速度方程式を解いて得られた
オゾン発生特性を表わす理論式と考えることができる が, オゾン発生特性の実験式としては次式のものが知 られている゙!.

$$
\begin{aligned}
& x=x_{0}\left(1-e^{-\alpha^{*} W / Q_{N}}\right) \\
& x: \text { オゾン濃度 }
\end{aligned}
$$

$x_{0}$ : 極限オゾン濃度

$\alpha^{*}$ : オゾナイザにより決る定数

(25)式はオゾン分解反応がオゾン濃度に関する一次反 応と仮定して得られた式と同一の形であり, 実用的に は分解は一次反応で扱えることを示している．(25)式の $x_{0}, \alpha^{*}$ はオゾナイザの構造, 使用条件により決る定数 とされているがてれらのパラメータと定数との関連は 明らかでない. (8)式と(25)式の間にはオゾン発生特性の 特有な現象として 1) $W / Q_{N}$ の小さなとてろで $\eta_{\max }$ が決まる，2） $W / Q_{N}$ の大きな所でオゾン濃 度は定常值（極限オゾン濃度）に達する，3）濃度は $W / Q_{N}$ の指数関数である等の共通点があり, てれら を対比することにより $\eta x_{0} ， \alpha^{*}$ とオゾナイザの種々の パラメータとの関連を明らかにするてとができる。ま ず極限濃度 $x_{0}$ と定常值 $\left(\left[\mathrm{O}_{3}\right] /\left[\mathrm{O}_{2}\right]\right)_{\mathrm{ss}}$ とから次の 対応が得られる。

$$
x_{0}=\left(\frac{\left[\mathrm{O}_{3}\right]}{\left[\mathrm{O}_{2}\right]}\right)_{\mathrm{ss}}=-\beta=\frac{1}{2} \frac{k_{1}}{k_{4}}\left\{\sqrt{1+4 \frac{k_{4}}{k_{1}} \gamma}-1\right\}
$$

従って $x_{0}$ は $k_{1}, k_{4}$ 即ち放電状感之 $k_{2}, k_{3}$ 即ち 放電空間の気体温度の両方の影響を受ける。(25)式より オゾン収率 $\eta$ を求めると次式となる.

$$
\begin{aligned}
\eta=Y_{\mathrm{O}_{3}} / W & =x Q_{N} / W \\
& =Q_{N} / W \cdot x_{0}\left(1-e^{-\alpha^{*} W / Q_{N}}\right)
\end{aligned}
$$

これより $\eta$ は $W / Q_{N}$ が小さくなるに従って増大し $\eta \max$ は次式となる.

$$
\eta_{\max }=x_{0} \alpha^{*}
$$

(28)式は(14)式と等しい.

$$
\therefore \eta_{\max }=x_{0} \alpha^{*}=2 k_{1} C_{1}
$$
(又は $2 k_{1 a} C_{1}$ )

これより $\eta_{\max }$ は放電の状態のみにより決ること がわかる. 指数関数の項を比較して

$$
\alpha^{*} \longleftrightarrow 2(\alpha-\beta) k_{4} C_{1}
$$

の対応が得られ，次式が成立する。

$$
\therefore \alpha^{*}=f\left(\alpha, \beta, k_{4}, C_{1}\right)
$$

$\alpha^{*}$ はオゾン分解に関係する項で放電の状態と放電 空間の気体温度の影響を受ける. 従ってオゾン発生特 性は(25)式が成立する範囲では $x_{0}, \alpha^{*}$ または $\eta_{\max }$ に より決まる. 


\section{2.3 オソン発生特性に影響を及ぼす要因}

オゾン発生特性に及ぼす要因は次の三つに大別され る.

a) $W / Q_{N}$ - (8)式拉よび(25)式から明らかなように, 発生特性に直接関係している要因である。

b) 放電の状態一一応速度定数 $k_{1}, k_{4}$ および $C_{1}$ は放電の状態に依存し， $x_{0} ， \alpha^{*}$ 亿影響を与え。 特に $\eta_{\max }$ は放電の状態のみにより決まる。

c ) 放電空間の気体温度一下応速度 $k_{2}, k_{3}$ は気体 温度に依存し $x_{0} ， \alpha^{*}$ 亿影響を与える。

これらの要因がオゾン発生特性に与える影響を, 設 計条件を考慮してパラメー夕は実用条件範井とし，以 下空気原料の場合について考察する.

(1) $W / Q_{N}$ とオゾン濃度

空気原料の場合には $W / Q_{N}, W / S$ が増大するとオ ゾン濃度が急激に低下し完全に零になることが観測さ れているが，実用的条件範囲ではオゾン濃度とW/QN の間には(8)式，(25)式の関係が成立する。 また $W / Q_{N}$ 之 共にオゾナイザ設計上重要なパラメータである放電電 力密度 $W / S$ については別途検討するが, 商用周波数 電源で投入できる程度の $W / S$ の場合その影響は小さ い, 従ってオゾナイザの構造, 使用条件が決まれば, 放電の状態, 放電空間の空気温度が一定となり, オゾ ン濃度は $W / Q_{N}$ のみの関数となる. 即ち $x_{0}, \alpha^{*}$ は 定数として扱うことができる. 毎時 $8 \mathrm{~kg}$ のオゾンを 生成するオゾナイザの特性を例にあげて説明する. 図 -5 は $W / Q_{N}$ とオゾン濃度の関係を示したものである. この時のオゾナイザの諸元および運転条件を表 2 亿示 す.

図の曲線は(25)式の形で表わすと次式となる（但し 濃度の単位は $\mathrm{mg} / \mathrm{Nl})$

$$
x=51\left(1-e^{-0.028 W^{\prime} Q_{N}}\right)
$$

実験式は $W / Q_{N}$ の $0 \sim 60$ の範囲で成立し $x_{0}=51$ $\mathrm{mg} / \mathrm{Nl}, \quad \alpha^{*}=+0.028 \mathrm{Nl} / \mathrm{min} / W$ はオゾナイザに より決る定数である.

（2）放電の状態関する要因

放電の状態に影響を与えるパラメータとしては放電 空隙長 $d$ 之放電空陌内圧 $P$ の積 $P \cdot d$, 原料空気の水 分, 誘電体の材質, 厚さ等がある. こてでは $P \cdot d$ お よび原料空気の水分について考察する.

(a) 放電空隙長拈よび放電空隙内圧力

(14)式， (29)式に示すように， $\eta_{\max }$ は $P \cdot d$ に依存す る. 空気原料の場合 $P \cdot d=91.2 \mathrm{~cm} \cdot$ Torr で $\eta_{\max }$ は極限に達するとの報告 ${ }^{1}$ がある，実装置の $P \cdot d$ に

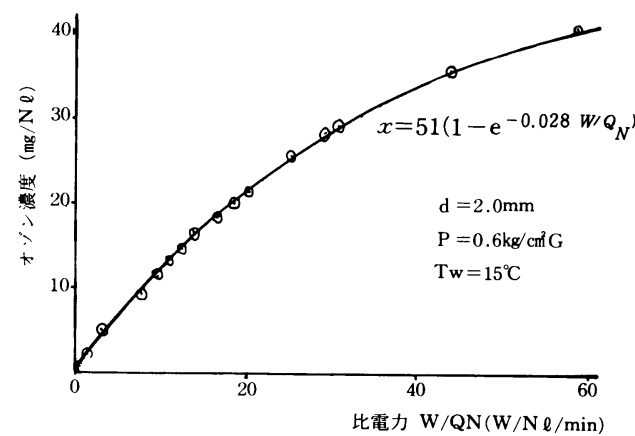

図-5 オン゙ン濃度一比電力 $\mathrm{W} / \mathrm{Q}_{N}$

表 2 オゾナイザ運転諸元

\begin{tabular}{|c|c|c|c|}
\hline 空 & 隙 & 2 & $\mathrm{~mm}$ \\
\hline 内 & 圧 & 0.7 & $\mathrm{~kg} / \mathrm{cm}^{2} \mathrm{G}$ \\
\hline \multicolumn{2}{|c|}{ 冷却水温度 } & 15 & ${ }^{\circ} \mathrm{C}$ \\
\hline 露 & 点 & -52 & ${ }^{\circ} \mathrm{C}$ \\
\hline \multicolumn{2}{|c|}{$W / S$} & 0.1 & $\mathrm{~W} / \mathrm{cm}^{2}$ \\
\hline
\end{tabular}

ついて検討すると $P$ はオゾンを処理工程に供給する装 置に依存し， $0.2 \sim 0.7 \mathrm{~kg} / \mathrm{cm}^{2} G$ 程度で使用される ことが多い。

また $d$ は高圧電極管，接地電極管の経済的な製作上 の問題から $1.5 \sim 2 \mathrm{~mm}$ 程度になる. 従って $P \cdot d$ は 約 $135 \sim 180 \mathrm{~cm} \cdot$ Torr の範用が実用されている. オ ゾン分解を含む全領域で，圧力の効果として Pが高い 方が空隙内の温度上昇を抑えることが知られており, $P$ の上昇によりオン゙ン収率は $W / S$ による差が小さく なるといわれている．実装置ではオゾン濃度 $10 \sim 20$ $\mathrm{mg} / N l$ 程度が殆んよ゙であり, 乙の時の $W / Q_{N}$ は 10 〜 $30 \mathrm{~W} / \mathrm{Nl} / \mathrm{min}$ 程度である. この範囲では $P$ による影響は小さい，従って $P$ を一定として $d$

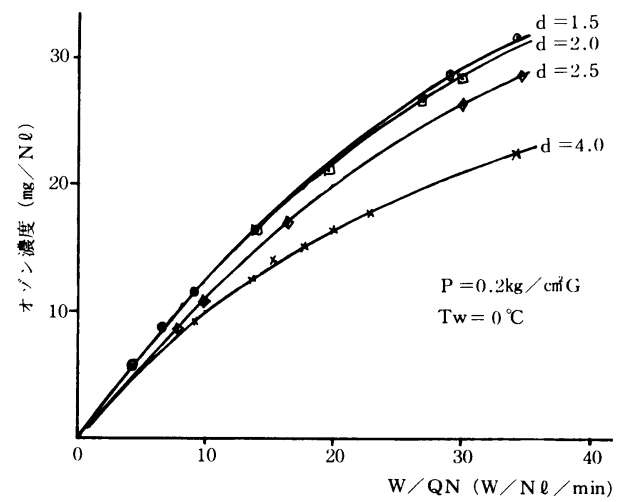

図-6 オゾン濃度一W/QN N （放電空隙長 $\mathrm{d}$ パラメー夕） 
をパラメータとした発生特性について考察する，P $=0.2 \mathrm{~kg} / \mathrm{cm}^{2} \mathrm{G}$ とした発生特性を図-6亿示す. また実 験式から得られた $x_{0}, \eta$ max を図-7 に示す。 $\eta_{\max }$ は予想された通り $d$ が大きくなるに従って低下してい る.

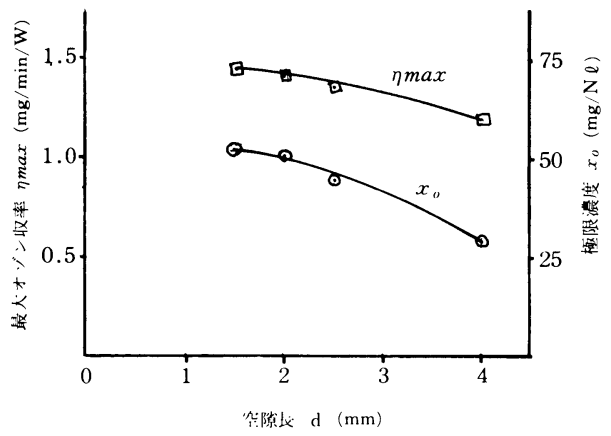

図-7 $\eta_{\max }, x_{0}$ 一放電空隙長

(b) 原料空気の水分

空気中の水分が放電の状態によ゙のように影響を与え るか, その機構は理論的には十分解明されてはいない が実験値として, 露点をパラメータとしたオゾン発生 特性を図-8に示す。また実験式から得られた $\eta$ max ,

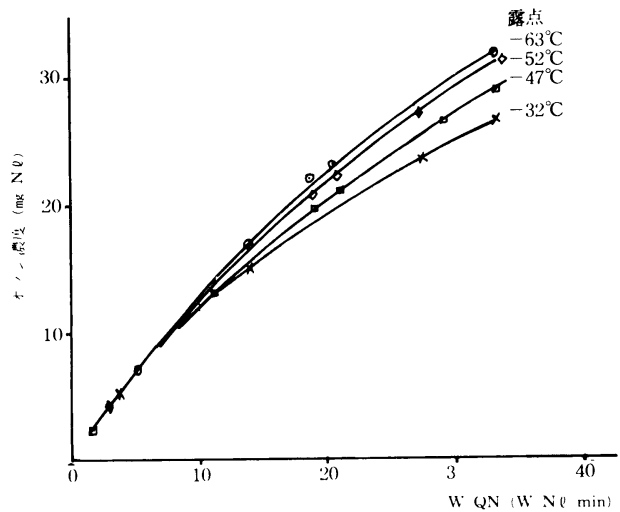

図-8 オゾン濃度一 $\mathrm{W} / \mathrm{Q}_{N}$ (露点パラメータ)

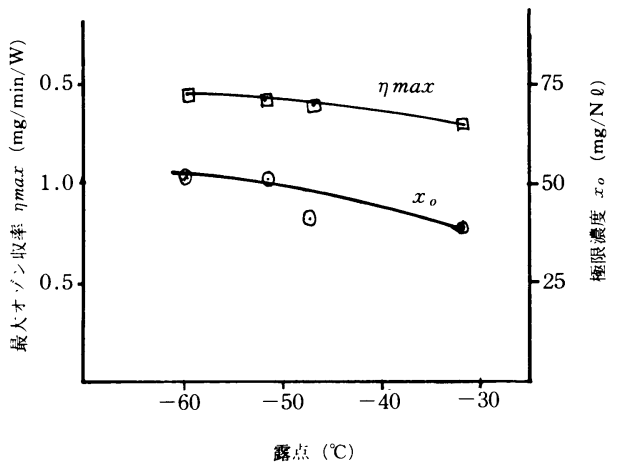

図-9 $\eta_{\text {max }}, x_{n}$ 一露点 $x_{0}$ を図-9 に示す。 $\eta_{\max }$ は露点が高くなるに従って 低下し，水分により放電の状態が変わることを示して いる. 水分を增すと $\eta_{\max }$ が低下する以上に $x_{0}$ の低 下が著しい，乙のことから水分が $k_{4}$ に大きな影響を 与えているものと予想される，実装置では露点は一 -50 ${ }^{\circ} \mathrm{C}$ 程度になるよう設計されているので，水分による才 ゾン収率に与える影響は少ない。

（3）放電空隙内の気体温度に関する要因 放電空隙内の気体温度 $T_{g}$ に影響を与えるパラメー 夕としては, 冷却水温度 $T_{W}$, 放電電力密度 $W / S$, 放電空隙長 $d$, 放電空隙内圧力 $P$ 等がある.

(a) 電極の温度分布

$T_{g}$ は当然のことながら電極の温度の影響を受ける と考えられるので, 簡略化した熱モデルにより電極の 温度分布とパラメータ $T_{W}, W / S, d$ との関係を説明 する.

ごく一般的なオゾナイザの電極断面を図-10 亿示す. 図のような電極構造の場合，無声放電が空隙部で一 様に発生し，軸方向の熱流はなく径方向の熱流のみと 仮定する。また高圧電極管内部の空気は熱伝達に殆ん よ゙寄与せず，断熱条件が成り立つものとして熱源を高 圧電極管の外表面として考えれば，熱の流れは高圧電 極管から冷却水へと流れる単純な図-10 に示す熱モデ ルとなる，熱源の熱密度は放電電力密度 $W / S$ の $95 \%$
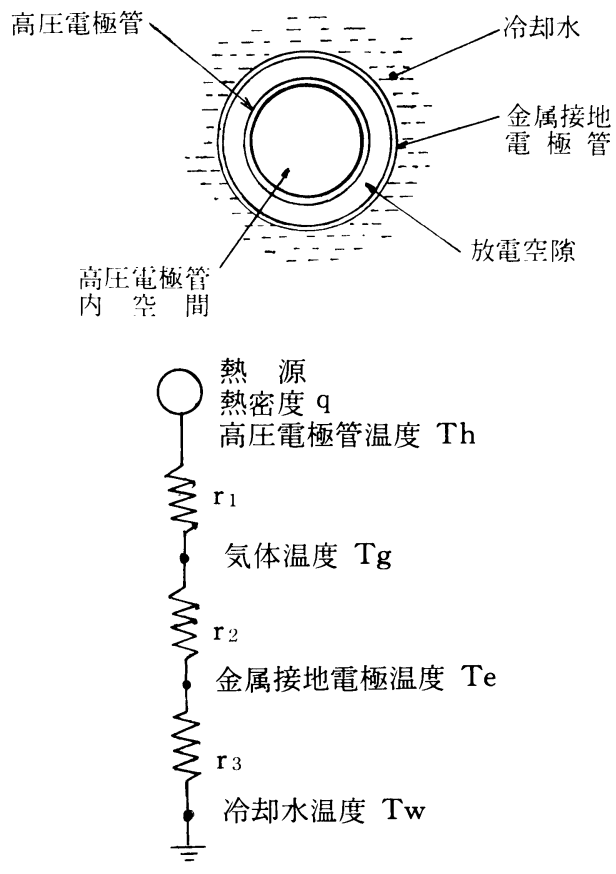

図-10 電極部の熱モデル 
と仮定すると各部の温度は次式となる

\section{接地電極温度}

$T_{e}=r_{3} \cdot q+T_{W}$

気体温度

$T_{g}=r_{2} \cdot q+T_{e}=\left(r_{2}+r_{3}\right) q+T_{W}$

高圧電極温度

$$
\begin{aligned}
& T_{h}=r_{1} q+T_{g}=\left(r_{1}+r_{2}+r_{3}\right) q+T_{W} \cdots \cdots \cdots(34) \\
& \text { ここに }
\end{aligned}
$$

$r_{1}$ : 高圧電極之空隙内空気之の熱抵抗

$r_{2}$ : 接地電極之空隙内空気之の熱抵抗

$r_{3}:$ 接地電極之冷却水との熱抵抗

$q: 0.95 \mathrm{~W} / S$ とおく.

$r_{1}, \quad r_{2}$ は二重円筒管の間の層流熱伝達の場合の外 面と内面の熱伝達率で決まり, 熱伝達率 $h$ は次式で与 えられる.

$$
\begin{aligned}
& h=\frac{\lambda}{2 d} C \\
& h: \text { 熱伝達率 } \\
& \lambda: \text { 流体の熱伝導率 } \\
& C: \text { 定数 } \\
& d: \text { 空隙長 }
\end{aligned}
$$

式の形より明らかなように熱伝達率は空隙長に反比 例する．従って熱抵抗は $d$ に比例して大きくなる． $r_{3}$ は円管群の層流熱伝達として考えるてとができ, 主に 冷却水の流速で決まる。実際には冷却水の流速はほぼ 一定になるように水量を決めるので $r_{3}$ は定数としてよ い. 以上の条件で求められた温度分布と実測結果を図 -11 亿示す． $W / S$ が大きくなるに従って実測値と計 算値との差が大きくなるのは，高圧電極管内の断熱条 件が成立しなくなることが原因だと予想される，空気 温度が計算値よりも低く $W / S$ が増してもそれ程増加 しないてとに関しては, 文献 ${ }^{2)}$ に指摘されていること 之一致しており，無声放電特有の現象であろう。温度 分布としては高圧電極管が最も高温であり熱源を高圧 電極管の外表面とするのは妥当だと考えられる．(33)式

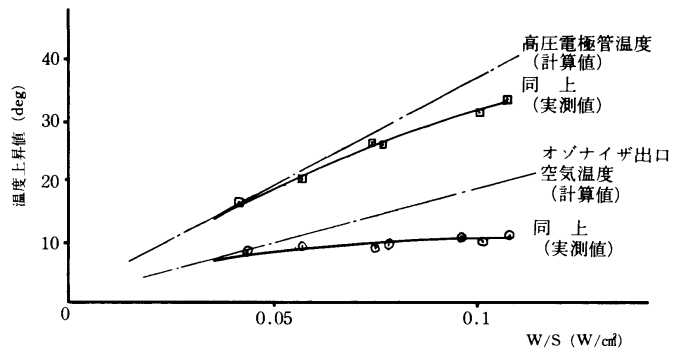

図-11 高圧電極管・オゾナイザ出口空気 温度上昇一 $\mathrm{W} / \mathrm{S}$
および(34)式から $W / S, d, T_{W}$ と空気温度, 高圧電極 管温度の関連を知ることができる．要約すれば $W / S$, $d$ を小さく $T_{W}$ を低くすることにより, 空隙内の空気 温度, 高圧電極管温度を低くすることができオゾンの 収率を向上することが可能である。

(b) 冷却水温度

(33)式より冷却水温度 $T_{W}$ は放電状態を変えずしかも 直接的に放電空隙温度に影響を与えるパラメータであ る. $T_{W}$ をパラメータとしたオン゙ン発生特性を図-12 に, その実験式を表 3 に示す．また極限濃度，最大才

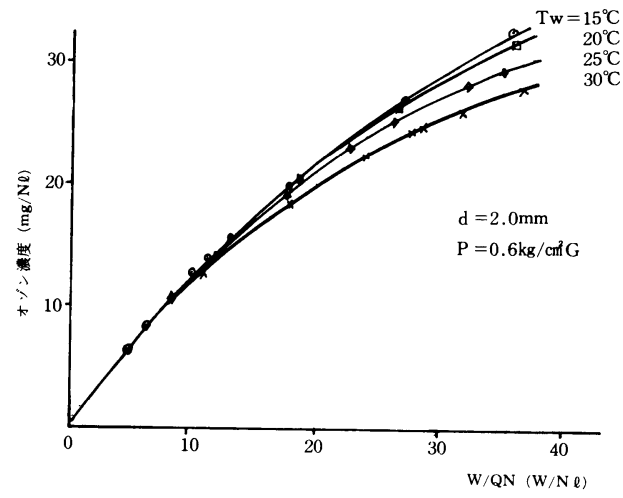

図-12 オゾン濃度一 $\mathrm{W} / \mathrm{Q}_{N}$

(冷却水温度 $\mathrm{T}_{\mathrm{w}}$ パラメータ)

表 $3 T_{W}$ をパラメータにした実験式

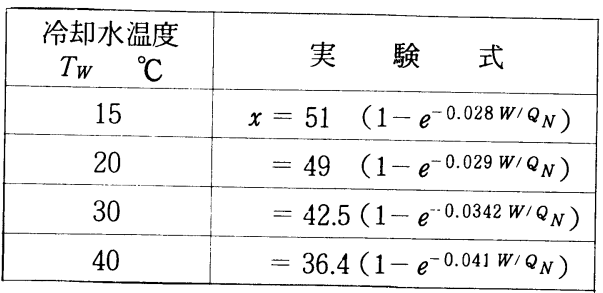

ゾン収率を図-13 に示す. 極限濃度は冷却水温度 $T_{W}$ が増すに従って減少し， $W / Q_{N}$ が大きくなると(11)式 の $k_{2} / k_{3}$ の項が温度により変化し影響することが考 えられる。一方最大オゾン収率は $T_{W}$ に関係なくほぼ 一定であり， $T_{W}$ が放電の状態に影響を与えないこと が分り(23)式が実機オゾナイザで略成り立つ之見られる. また図-13より, 実用条件範囲であるオン゙ン濃度 12 $\mathrm{mg} / \mathrm{Nl}$ ではオゾン収率 $\eta$ が $T_{W}=10 \sim 40{ }^{\circ} \mathrm{C}$ 範囲 で高々 $3 \%$ 程度の低下しか示さない，例えば， $T_{W}=$ $20{ }^{\circ} \mathrm{C}$ ではオゾン収率 $1.28 \mathrm{mg} / \mathrm{min} \cdot \mathrm{W}$ （電力効率 13 $\mathrm{kW} \cdot \mathrm{Hr} / \mathrm{kg}$ ）となり, 後述のように放電空隙 $d=2$ $\mathrm{mm}$ 前後では冷却水温度 $T_{W}$ の影響が非常に小さく なり, 常温清水 $\left(20 \sim 25^{\circ} \mathrm{C}\right)$ での冷却で十分であるて 


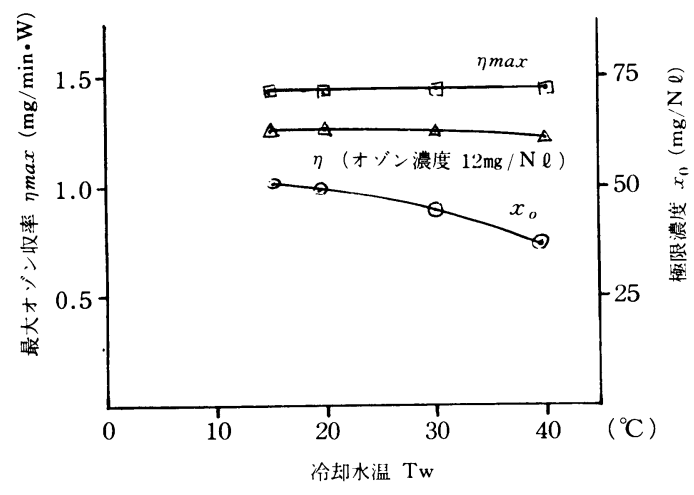

図-13 $\eta_{\max }, \eta, x_{0}$-冷却水温度 $\mathrm{TW}$

とを示している.

(c) 放電電力密度

放電電力密度 $W / S$ はすでに述べたように, 商用周 波数電源の場合 $0.1 \sim 0.15 \mathrm{~W} / \mathrm{cm}^{2}$ 程度であり, $W /$ $Q_{N}=0 \sim 20 \mathrm{~W} / \mathrm{Nl} / \mathrm{min}$ の範井では $W / S$ の影響は 小さくオゾン発生特性は $W / Q_{N}$ によって決まる。 て こでは, 更に高周波数電源を使用して $W / S>0.15 \mathrm{~W} /$ $\mathrm{cm}^{2}$ とした場合を含めて, オゾン濃度と $W / Q_{N}$ の関 係を $W / S$ をパラメータとして図-14 に示す.てのよ うに, $d \simeq 2 \mathrm{~mm}$ では $W / S \geqq 0.3 \mathrm{~W} / \mathrm{cm}^{2}$ で, オゾ ン濃度が $15 \mathrm{mg} / N l$ 以上で $W / S$ の影響が出始める. 即ちオゾン収率の低下につながる。

(d) 放電空隙長

熱モデルにおける熱抵抗 $r_{2}$ は空隙長に比例して大 きくなると考えられる. 電極の温度は熱流の強さと熱 抵抗の積に $T_{W}$ を加えたものである．従って $T_{W}$ が一 定であれば, 熱流の強さ即ち $W / S$ と熱抵抗即ち $d$ を 小さくすることにより放電空隙内の空気温度は低く保 たれ，W/QN の小さな範囲では $W / S, d$ の熱的影

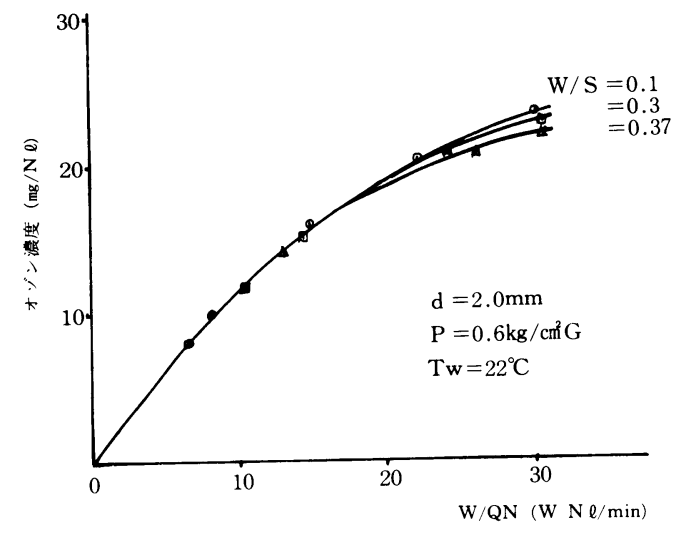

図-14 オゾ:濃度一W/ $\mathrm{Q}_{N}$ (W/Sパラメータ)
響は少ないと考えられる。しかし熱抵抗が大きくなる に従って $r_{2}$ 部分の温度差が影響を与えることは容易 に予想され， $d$ を出来る限り小さくするてとによって 熱的には次のような利点が考えられる.

- $W / S$ の影響を受けない $W / Q_{N}$ の範囲が広くなる. $W / S$ を大きくとっても同一 $W / Q_{N}$ に対して生成才 ゾン濃度は変わらない。

- 同一 $W / S$ に対して極限濃度が大きくなる.

- 冷却水温度, 気体圧力が变動しても発生特性は安定 である。

\section{4. オソナイザ最適設計に関する考察}

前記の諸特性の検討結果に基づきオゾナイザの設計 法を考察する.

一般にオゾナイザの設計条件として処理対象の性 質, 規模, 処理方法等によりオゾン生成量 $Y_{\mathrm{O}_{3}}$, オゾ ン濃度 $x$, オゾナイザ吐出圧（一般には空隙内圧力に ほぼ等しい）が決められる．冷却水の種類はオゾナイ ザの立地条件により異なり, 水質及び水量がオゾナイ ザ冷却水としての仕様を満足している場合は, 常温清 水が使同され泠却水温度 $T_{W}=20 \sim 25^{\circ} \mathrm{C}$ となる。 ま た冷却水として処理水とか海水を使用する場合は, 水 対水の熱交換器による間接冷却方式が採用され $T_{W}=$ 20 35 으 が与えられる. これらの条件を満足する実 験式があらかじめ求められているとして, オン゙ナイザ の主要諸元について次の様に設計できる. 生成量 $Y_{\mathrm{O}_{3}}$ $=\left(Y_{\mathrm{O}_{3}}\right)_{P}$, オゾン濃度 $x=x_{P}$ として空気流量 $\left(Q_{N}\right)_{P}$ を求める.（それぞれ内圧 $P$ 時の諸元を示す.)

$\left(Q_{N}\right)_{P}=\left(Y_{\mathrm{O}_{3}}\right)_{P} / x_{P}$ (36)

実験式として次式が得られている故

$x=\left(x_{0}\right)_{P}\left(1-e^{-\alpha * W^{\prime} Q_{N}}\right)$ (37)

$x=x_{P}$ として $\left(W / Q_{N}\right)$ を求める.

$x_{P}=\left(x_{0}\right)_{P}\left\{1-e^{-\alpha_{P}^{*}\left(W / Q_{N}\right)} \rho\right\}$

$\therefore\left(\frac{W}{Q_{N}}\right)_{P}=\frac{1}{-\alpha_{P}^{*}} \ln \left\{\frac{\left(x_{0}\right)_{P}-x_{P}}{\left(x_{0}\right)_{P}}\right\}$

これより濃度 $x_{P}$ となる $W / Q_{N}$ が求まりオゾンを $\left(Y_{\mathrm{O}_{3}}\right)_{P}$ 生成するのに必要なる放電電力は次式となる.

$(W)_{P}=\left(W / Q_{N}\right)_{P} \cdot\left(Q_{N}\right)_{P} \quad \cdots \cdots \cdots \cdots \cdots \cdots(39)$

またこの時の $\eta$ および $\eta_{\max }$ は次のようになる.

$\eta=\left(Y_{\mathrm{O}_{3}}\right)_{P} /(W)_{P}=x_{0} \cdot 1 /\left(W / Q_{N}\right)_{P} \cdots \cdot(40)$

$\eta_{\max }=\alpha_{P}^{*} \cdot\left(x_{0}\right)_{P}$

具体例として $x=16 \mathrm{mg} / N l$ とした時の数值を表 4 亿示す.

次に前記諸特性を勘案して得られる放電電力密度 
表 $4 x_{P}=16 \mathrm{mg} / \mathrm{Nl}$ のときの計算例

\begin{tabular}{|c|rl|}
\hline$\left(Y_{\mathrm{O}_{3}}\right)_{P}$ & 8 & $\mathrm{~kg} / \mathrm{Hr}$ \\
\hline$x_{P}$ & 16 & $\mathrm{mg} / \mathrm{Nl}$ \\
\hline$\left(Q_{N}\right)_{P}$ & 500 & $\mathrm{Nm} / \mathrm{Hr}$ \\
\hline$\left(W / Q_{N}\right)_{P}$ & 13.4 & $\mathrm{~W} / \mathrm{Nl} / \mathrm{min}$ \\
\hline$W_{P}$ & 112 & $\mathrm{~kW}$ \\
\hline$\eta$ & 1.19 & $\mathrm{mg} / \mathrm{min} \cdot \mathrm{W}$ \\
\hline $1 / \eta$ & 14 & $\mathrm{~kW} \cdot \mathrm{Hr} / \mathrm{kg}$ \\
\hline$\eta_{\max }$ & 1.428 & $\mathrm{mg} / \mathrm{min} \cdot \mathrm{W}$ \\
\hline
\end{tabular}

$W_{P} / S$ より必要な総放電面積 $S$ がわかるから所要電 極管総本数が求まる. また印加電圧, 周波数等の電気 諸元は(3)式より得られる.

\section{5. むすび}

空気原料を使用した無声放電式オゾナイザの放電電 力に対するオゾン発生量の関係を実機オゾナイザにお いて各種パラメータを変化させ実用条件範囲で求めそ の結果をオゾン生成反応式および実験式と関連づけて 考察し最後にオゾナイザの最適設計法を試みた。主な 結果は次の通りである.

（1）実用条件範囲では実機オゾナイザの各種パラメー 夕に対するオゾン濃度と $W / Q_{N}$ の関係はほぼ実験式 で表わされるし, 実験式が与えられると任意のオン゙ン 濃度における $W / Q_{N}$ が求まり, オゾンを生成するに 必要な放電電力が得られる. 同時にそのオゾン濃度に 対応したオゾン収率が求められる.

（2）冷却水温度 $T_{W}$, 放電空吵長 $d$ のいずれのパラメ 一タに対してあオゾン濃度が濃くなるに従い, $W / Q_{N}$ の増分は指数関数で増加するためオゾン収率は低下し てゆく.
（3）冷却水温度 $T_{W}$ が上昇すると極限オゾン濃度が低 下するが, しかし, 放電空隙長 $d$ が $2 \mathrm{~mm}$ 程度で $T_{W}$ $=10 \sim 40^{\circ} \mathrm{C}$ 冷却範囲ではオゾン収率の低下はほぼ $3 \%$ 内と小さく冷却水として常温清水 $\left(20 \sim 25^{\circ} \mathrm{C}\right)$ で 十分である。

(4) 放電空隙長 $d$ をさくすることにより $W / S$ の影 響を受けない $W / Q_{N}$ の範囲が広くなる，特に $d$ が 2 $\mathrm{mm}$ 以下でその効果は大きい.

(5) オゾナイザの設計条件としてオゾン生成量 $Y_{\mathrm{O}_{3}}$, オゾン濃度 $x$, オゾナイザの吐出圧力及び冷却水温度 が与えられると，実験式(31)を用いることにより所要の 気体流量, 放電電力, オゾン収率の諸元が判明し, $W$ IS の関連から電極管本数が決まり同時にその他の電 気諸元が決められる.

今回の考察の結果, 本報告に使用したオゾナイザは, 従来形オゾナイザに比してオゾン収率で15～20\%の向 上がみられ，且つ高濃度，過酷な冷却の下でも十分実 用条件を満足することがわかった．乙れは高圧電極管 の特殊製作技術の確立により，金属接地電極管並みの 加工精度でガラス管を製作する事が可能になったこと に起因するもので, 現在新形シリーズのオゾナイザと して完成されたてとを付記しておく，本稿が技術者， 研究者各位の参考になれば幸いである。

\section{参考文献}

1) 田畑, 田中, 八木: 電気学会誌 $97 \mathrm{~B} 11,665$ (昭52-11)

2 ) 田畑, 田中, 八木 : 電気学会誌 97 B 2，100(昭52-2)

3 ) 八木, 田畑 : 電気学会誌 96B11, 569 (昭51-11)

4 ) 電気学会オゾナイザ専門委員会編：オゾナイザハンドブッ ク p.202 (昭35-6)

5 ) 田畑, 八木：電気学会誌 95 B 5, 249 (昭50-5)

6 ）藤, 竹村 : 電気試験所研究報告№ 698 p. 95 (昭44-5) 